\title{
Life Cycle Assessment of Fish Culture in Thailand: Case Study of Nile Tilapia and Striped Catfish
}

\author{
Patcharaporn Pongpat and Rungnapa Tongpool
}

\begin{abstract}
This study was aimed to assess environmental impacts of fish culturing in Thailand using life cycle assessment (LCA) method. The scope was a cradle-to-gate study of red nile tilapia (Oreochromis niloticus) and striped catfish (Pangasianodon hypophthalmus). The impact assessment method of CML Baseline 2000 was applied to evaluate the impacts in the categories of abiotic depletion, acidification and global warming. The impacts of red nile tilapia were 3-4 times higher than those of striped catfish. The global warming potential of red nile tilapia was $2.96 \mathrm{~kg} \mathrm{CO}_{2} \mathrm{eq}$, where as that of striped catfish was $1.01 \mathrm{~kg} \mathrm{CO}$ eq. The feeds, especially fish meal, were the main impact contributors. Small replacement of fish meal with soybean meal while maintaining the growth rate of the fish was possible. This leaded to slightly decrease in the environmental impacts. The environmental performance of fish meal itself should be improved in order to reduce the impacts from fish culture.
\end{abstract}

Index Terms - Fish culture, LCA, Nile tilapia, striped catfish.

\section{INTRODUCTION}

Aquaculture is the fastest growing food-producing sector in the world [1]. Aquaculture plays an increasingly important role in food security and the economy of Thailand [2]. Freshwater aquaculture is mainly for domestic consumption. Small-scale freshwater aquaculture is important in providing high quality protein food for rural poor people. Freshwater aquaculture produces medium-value products for export. In 2010, total production from freshwater aquaculture was 496,599 tons as shown in Fig. 1. The main freshwater fish cultured were nile tilapia (Oreochromis niloticus), walking catfish (Clarias batrachus), snakedskin gourami (Trichogaster pectoralis) and striped catfish (Pangasianodon hypophthalmus). The production of freshwater culture in Thailand has been the same from 2005 to 2010 and some have been the same for more than ten years (Fig. 2). The improvement of fish culture should be paid attention to meet up with an increasing demand of the world.

The striped catfish from Thailand is called 'tropical white fish' in Europe. The term 'tropical white fish' is commonly used to designate the fish with white flesh, such as cod, hake, Alaska Pollock, which are common in European [4]. This

Manuscript received April 25, 2013; revised June 25, 2013. This work was supported in part by the National Science and Technology Development Agency (NSDTA) Thailand, under the Thailand National LCI Database Project.

All the authors are with the National Metal and Materials Technology Center, Pathumthani, 12120 Thailand (e-mail: patcharp@mtec.or.th, rungnapt@mtec.or.th). sector has to overcome trade embargoes and related restrictions that are imposed by certain importing countries [5]. Currently, such barriers on the striped catfish from Thailand do not exist in most importing countries. However, food safety and food quality standards are still enforced. Concerns on fish quality and environment of farming system have been raised.

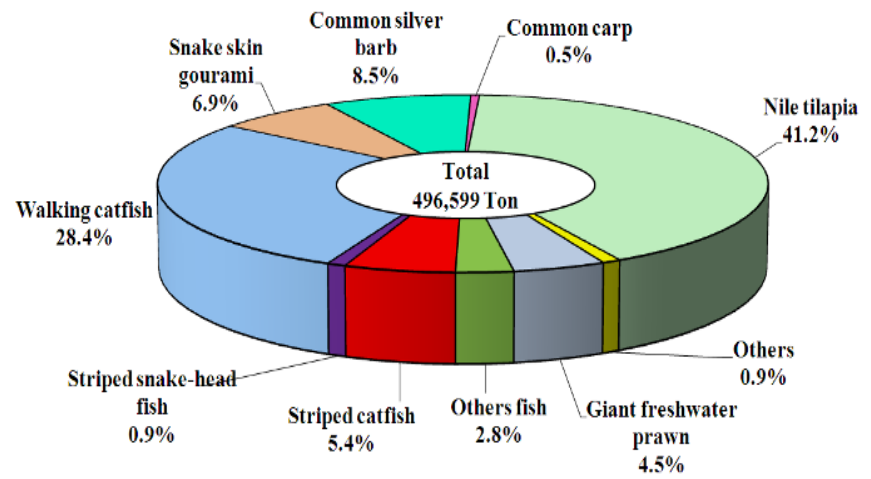

Fig. 1. Production of freshwater culture by species in 2010 [3].

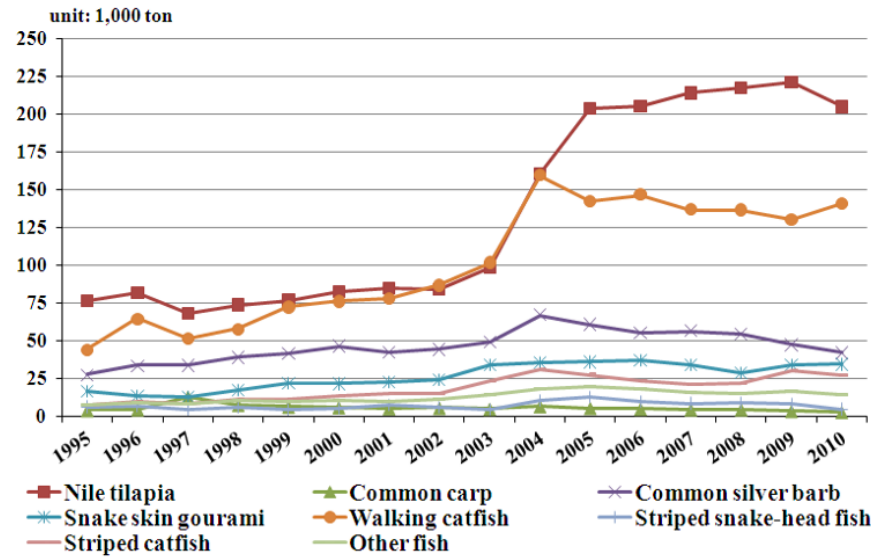

Fig. 2. Production of freshwater culture by species, 1991-2010 [3].

As mentioned above that nile tilapia and striped catfish are important in the fish industry of Thailand. The resource used and emissions from the cultures affects environment status of the country. This study was aimed to evaluate the environmental impacts from the production of these two fish using life cycle assessment (LCA) method and to identify of environmental hot spots (activities contributing large impacts). The result of this study will be beneficial for farmers to see possible approaches in improving the management and practices in the farms. This will subsequently reduce the environmental impacts of the fish and increase their competitiveness in the world and domestic market. 


\section{Methodology}

LCA is a comprehensive environmental accounting tool with well-established procedures and international standard [6]. There are four steps in LCA, which are goal and scope definition, life cycle inventory (LCI) analysis, life cycle impact assessment (LCIA), and interpretation. LCA has been used to evaluate environmental performance of fishery and seafood products [7].

\section{A. Goal}

The goal of this study was to evaluate environmental impacts of nile tilapia and striped catfish using LCA and CML Baseline 2000 assessment method. The result of this study could be helpful for the stakeholders of fishery industry and policy-makers in Thailand in order to understand the problem of fishery production, providing scientific proof on environmental impacts in several categories.

\section{B. Scope}

The scope of this study is shown in Fig. 3. The culture system of nile tilapia and striped catfish included preparation of pond and floating basket (cage), as well as feeding fish and harvesting. Natural resources used and emissions from the production of chemicals and feeds are included, i.e., a cradle-to-gate study. Transportation data was excluded.

There are two main types of nile tilapia; Chitralada strain (normal tilapia) and Tabtim strain (red nile tilapia). They can be cultured in cages and in ponds [8] as shown in Fig. 4. In this work, red nile tilapia was studied. In Thailand, most of the red nile tilapia is cultured in fish cages and striped catfish (known as "Sa-Wai" in Thai) is cultured in ponds.

Various substances and energy used in each process were included in the inventories. The background data of certain processes and chemicals could not be found, and thus they were excluded from the scope of this study. The total exclusion was less than $1 \%$ by weight.
The functional unit (FU) was defined as $1 \mathrm{~kg}$ of fish.

\section{Life Cycle Inventory Analysis}

The gate-to-gate inventory data were obtained from the project "Development of National Life Cycle Inventory Database of Food and Agriculture" by National Metal and Materials Technology Center and University of Payao under the Thai National Life Cycle Inventory Database Development Project, carried out according to ISO 14040 [9]. Data collection was obtained from the fish farm in Thailand in 2012.

The inventories of the nile tilapia and striped catfish included all inputs, e.g., feeds, chemicals, fuel, as well as all outputs, e.g., product, air emission, solid waste and dead fish. Water supply for the farms was obtained from river, streams and canals. Harvesting was done using seine nets after draining $60-80 \%$ of the water in the pond.

Amount of $\mathrm{CO}_{2} \mathrm{CH}_{4}$ and $\mathrm{N} 2 \mathrm{O}$ from fuel combustion was calculated using emission factors of IPCC 2006 [10]. Data on emissions of $\mathrm{CO}, \mathrm{SO}_{2}, \mathrm{NOx}, \mathrm{NMVOC}$ and PM10 were calculated using emission factors from EMEP/EEA air pollutant emission inventory guidebook 2009 [11]. The background data of each input was chosen from Ecoinvent database to obtain cradle-to-gate inventory.

\section{Life Cycle Impact Assessment (LCIA)}

The impact assessment method of CML Baseline 2000 was used via SimaPro 7.3 software [12]. The impact categories of interest were abiotic depletion (ABD) (unit: $\mathrm{kg} \mathrm{Sb}$ eq), acidification potential (ACD) (unit: $\mathrm{kg} \mathrm{SO} 2 \mathrm{eq}$ ), global warming potential (GWP100) (unit: $\mathrm{kg} \mathrm{CO} 2$ eq) [12]. This method provides summation of the environmental impacts occurred throughout the scope of this study. Global warming potential, acidification and abiotic depletion have been typically included as impact categories in LCA studies of seafood products [1].

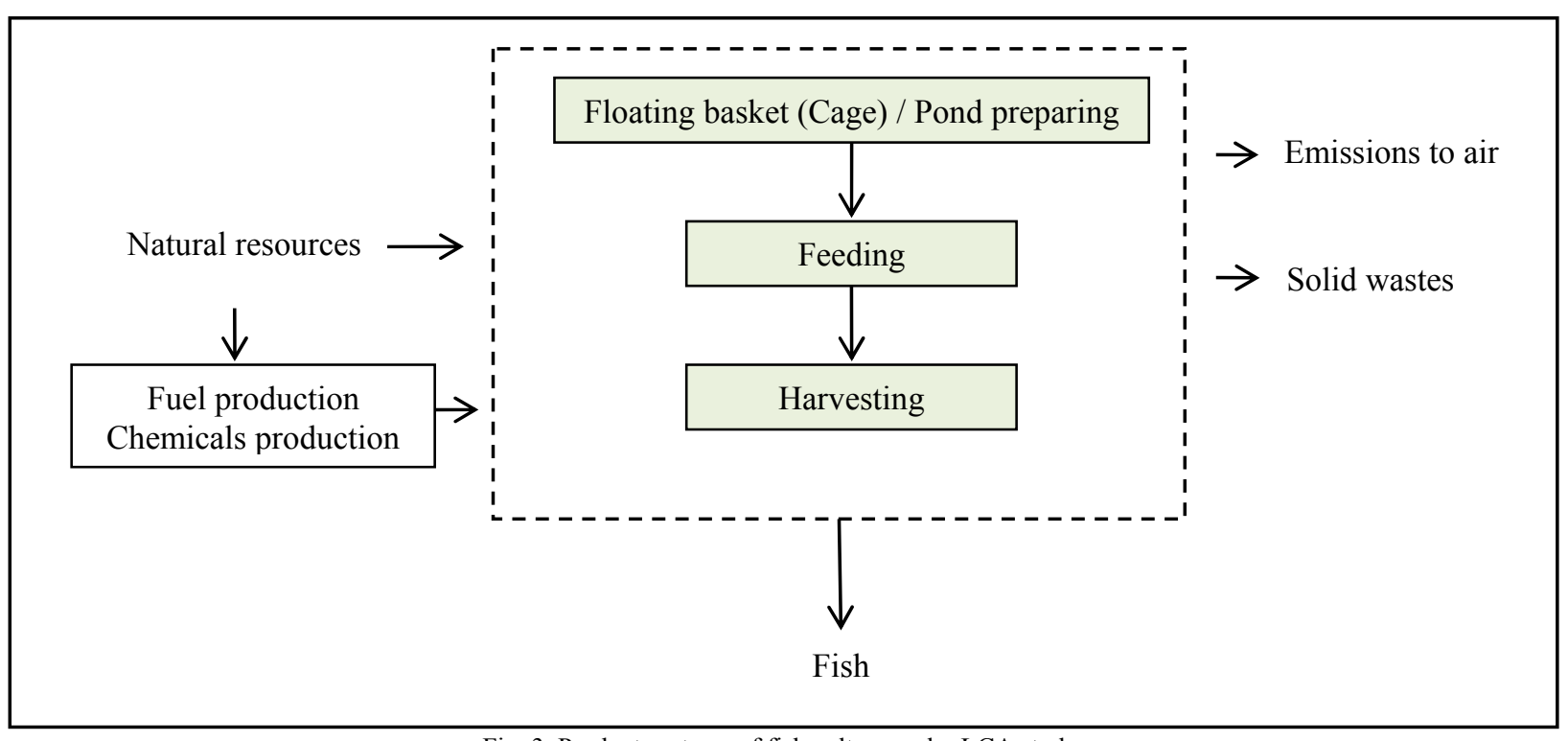

Fig. 3. Product systems of fish culture under LCA study. 


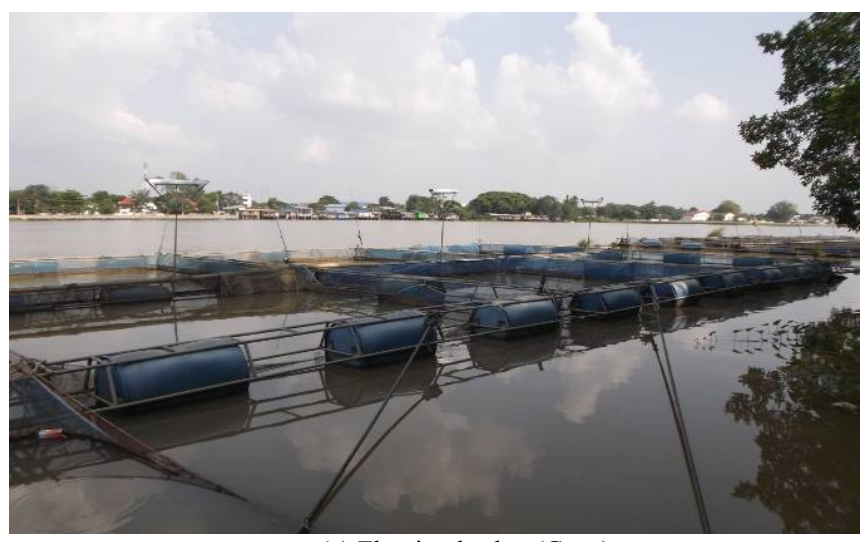

(a) Floating basket (Cage)

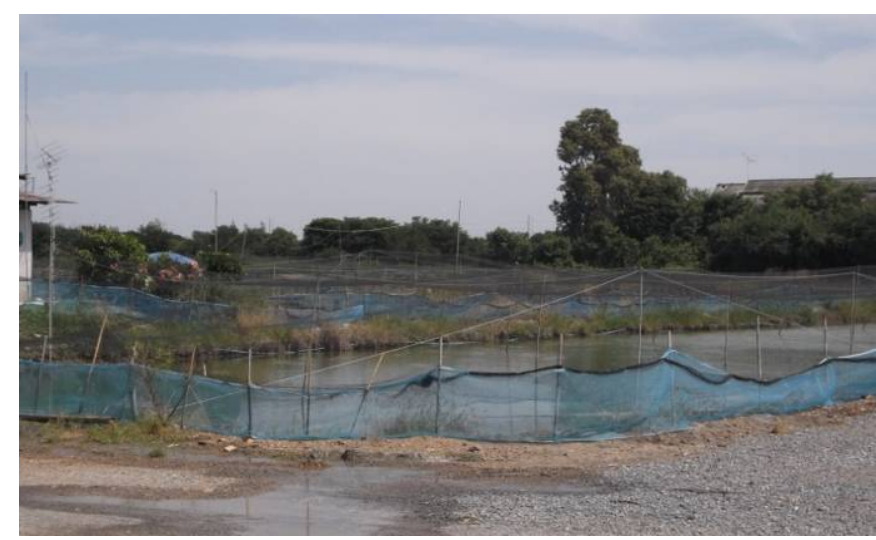

(b) Pond

Fig. 4. Common types of fish culture in Thailand

\section{RESUlTS AND DisCUSSION}

The environmental impacts of the fish are shown in Table I. It can be seen that the red nile tilapia had higher environmental impacts than the striped catfish in all categories. The sources contributing to the environmental impacts, shown in Fig. 5, were categorized as (i) impacts from farming (shown as Farm), (ii) fish meal, (iii) soybean meal, (iv) rice bran, (v) maize starch, (vi) vegetable oil and (vii) vitamin C. Fish meals shared large contributions in all categories. Maize starch shows relatively high impact in the category of abiotic depletion. Contributions from soybean meal played important role in the categories of abiotic depletion and global warming potential.

The environmental impacts of striped catfish are shown in Fig. 6. Fish meal was also the main impact contributors in all categories. Soybean meal played important role in the categories of abiotic depletion and global warming. Rice bran shows relatively large contribution in global warming.

The CML Baseline 2000 assessment method has been used to study environmental impacts of seafood [12]-[14]. Table II shows the environmental impacts of trout and salmonid, produced by common technology and assessed within the same scope as the red nile tilapia and striped catfish. It can be seen that striped catfish had the lowest impact. This is because the striped catfish was fed with left over agricultural products such as chicken intestine and swine dung which had no environmental burden. The use of swine dung generated planktons which were eaten by the striped catfish.

TABLE I: ENVIRONMENTAL IMPACTS OF 1 Kg OF NILE TILAPIA AND STRIPED CATFISH.

\begin{tabular}{|l|c|r|r|}
\hline Impact category & Unit & Red Nile Tilapia & Striped Catfish \\
\hline Abiotic depletion & $\mathrm{kg} \mathrm{Sb} \mathrm{eq}$ & 0.0024 & 0.0006 \\
\hline Acidification & $\mathrm{kg} \mathrm{SO} 2 \mathrm{eq}$ & 0.0408 & 0.0093 \\
\hline Global warming & $\mathrm{kg} \mathrm{CO} 2 \mathrm{eq}$ & 2.9600 & 1.0142 \\
\hline
\end{tabular}

TABLE II: THE IMPACT ON GLOBAL WARMING FROM THE PRODUCTION OF 1

\begin{tabular}{|l|c|r|r|}
\hline \multicolumn{4}{|c|}{ KG FISH } \\
\hline Impact category & Unit & \multicolumn{1}{c|}{ Trout [13] } & \multicolumn{1}{c|}{ Salmonid [14] } \\
\hline Abiotic depletion & $\mathrm{kg} \mathrm{Sb} \mathrm{eq}$ & Not available & 0.0109 \\
\hline Acidification & $\mathrm{kg} \mathrm{SO} 2 \mathrm{eq}$ & 0.0105 & 0.0166 \\
\hline Global warming & $\mathrm{kg} \mathrm{CO} 2 \mathrm{eq}$ & 2.1561 & 1.4379 \\
\hline
\end{tabular}

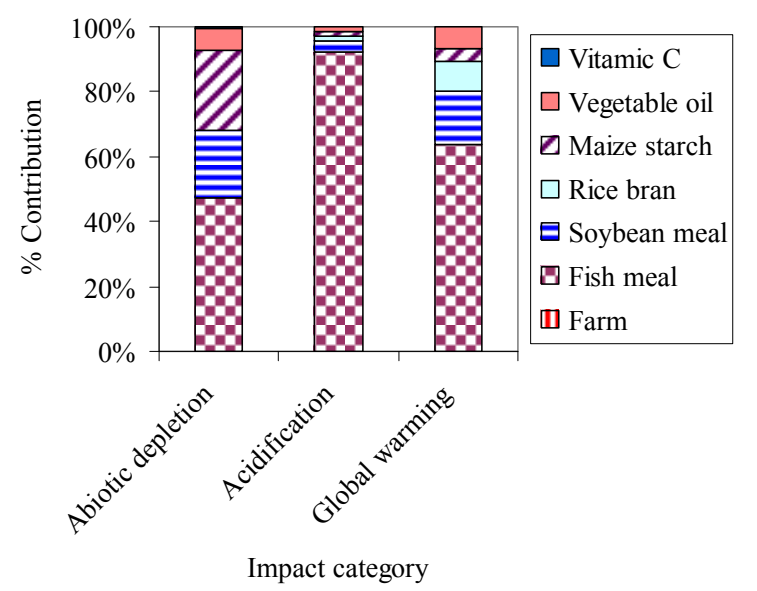

Fig. 5. Impact contributions from the components used to produce $1 \mathrm{~kg}$ of red nile tilapia.

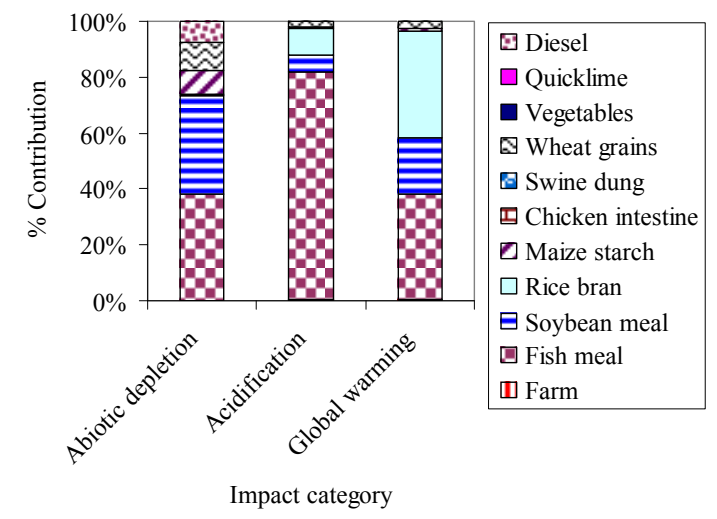

Fig. 6. Impact contributions from the components used to produce $1 \mathrm{~kg}$ of striped catfish.

It can be seen that the impact of red nile tilapia are higher than trout, salmonid and striped catfish. Therefore farmers should find alternative feed sources that would not interrupt the growth rate of fish. It was reported that when $30 \%$ of fish meal protein was replaced by soybean meal for the feeds containing $32 \%$ protein, the growth rate of nile tilapia was changed [15]. However when the feeds contained $24 \%$ protein, the $30 \%$ replacement gave the same result as the control group (no fish meal replacement).

The scenario was modeled in this study and find out how much the environmental impact can be reduced. One fifth of fish meal protein was replaced by soybean meal, giving the feeds the same protein content. The environmental impacts of the scenario are shown in Table III. It can be seen that the impact reduction in the category of acidification for the red 
nile tilapia and striped catfish was 17.6 and $15.6 \%$, respectively. The reductions in the other two categories were relatively low. If the ratio of fish meal was further decreased, the grow rate of fish could be reduced. Therefore the impact of fish meal itself should be paid attention.
Table IV shows environmental impacts of $1 \mathrm{~kg}$ of fish meal produced from trash fish [16]. The impact in the category of global warming was as high as $5.7 \mathrm{~kg} \mathrm{CO}_{2} \mathrm{eq} / \mathrm{kg}$. Environmental performance of fish meal should be improved.

TABLE III: ENVIRONMENTAL IMPACTS OF $1 \mathrm{KG}$ OF RED NILE TILAPIA AND STRIPED CATFISH ACCORDING TO THE SCENARIO.

\begin{tabular}{|c|c|c|c|c|c|}
\hline \multirow{2}{*}{ Impact category } & \multirow{2}{*}{ Unit } & \multicolumn{2}{|c|}{ NILE TILAPIA } & \multicolumn{2}{|c|}{ STRIPED CATFISH } \\
\cline { 3 - 6 } & & Scenario & \% Reduction & Scenario & \% Reduction \\
\hline Abiotic depletion & $\mathrm{kg} \mathrm{Sb} \mathrm{eq}$ & 0.0023 & 3.9 & 0.0006 & 3.2 \\
\hline Acidification & $\mathrm{kg} \mathrm{SO}_{2}$ eq & 0.0336 & 17.6 & 0.0079 & 15.6 \\
\hline Global warming & $\mathrm{kg} \mathrm{CO}_{2}$ eq & 2.7127 & 8.4 & 0.9643 & 4.9 \\
\hline
\end{tabular}

TABLE IV: THE ENVIROMENTAL IMPACTS FROM THE PRODUCTION OF $1 \mathrm{KG}$ FISH MEAL FROM TRASH FISH.

\begin{tabular}{|c|c|c|}
\hline Impact category & Unit & Impact \\
\hline Abiotic depletion & $\mathrm{kg} \mathrm{Sb}$ eq & 0.0035 \\
\hline Acidification & $\mathrm{kg} \mathrm{SO} 2 \mathrm{eq}$ & 0.1139 \\
\hline Global warming & $\mathrm{kg} \mathrm{CO} 2 \mathrm{eq}$ & 5.6921 \\
\hline
\end{tabular}

\section{CONCLUSIONS}

Life cycle assessment was used to evaluate the environmental impact of red nile tilapia and striped catfish culture and to identify environmental hot spots. The results revealed that the feeds, especially fish meal, were the biggest impact contributor. Small replacement of fish meal with soybean meal while maintaining the growth rate of fish was possible. This leaded to the environmental impact reduction in the category of acidification. The impacts in the categories of abiotic depletion and global warming were slightly changed. Therefore the environmental performance of fish meal itself should be improved.

\section{ACKNOWLEDGMENT}

The authors acknowledge the funding support from National Science and Technology Development Agency (NSTDA), Thailand. We appreciate University of Payao for LCI data collection of this study. We also acknowledge Assoc. Prof. Dr. Thumrongrut Mungcharoen and Ms. Chantana Yuvaniyama, the experts at National Science and Development Agency (NSTDA), for the advice on the Thai National Life Cycle Inventory Database Development Project.

\section{REFERENCES}

[1] Food and Agriculture Organization (FAO), The State of World Fisheries and Aquaculture 2012, Rome, 2012, pp. 3.

[2] Food and Agriculture Organization of the United Nations. (2013). National Aquaculture Sector Overview Thailand. [Online]. Available: http://www.fao.org/fishery/countrysector/naso_thailand/en.

[3] Ministry of Agriculture and cooperatives, Department of Fisheries, Information Technology Center, Fisheries Statistics of Thailand 2010, 2012, pp.7.

[4] P. Chaiyasena, Monthly Report on Striped Catfish and Its Products, Thailand: Fisheries Economics Division, 2011, pp.1.

[5] L. T. Phan, T. M. Bui, T. T. T. Nguyen, G. J. Gooley, B. A. Ingram, H. V. Nguyen, P. T. Nguyen, and S. S. De Silva. (November 2009). Current status of farming practices of striped catfish, Pangasianodon hypophthalmus in the Mekong Delta, Vietnam. Aquaculture. [Online].
296(3-4). pp. 227-236. Available: http://www.sciencedirect.com/ science/article/pii/S0044848609007066.

[6] International Organization for Standardization (ISO), "ISO14044 Environmental management-life cycle assessment-requirements and guidelines," Geneva, Switzerland, 2006.

[7] A. Hospido and P. Tyedmers. (November 2005). Life cycle environmental impacts of Spanish tuna fisheries. Fish Res. [Online]. 76 (2). pp. 174-186. Available: http://www.sciencedirect.com/ science/article/pii/S016578360500175X .

[8] J. Kasornchandra, Historical Development of Aquaculture in Thailand, Thailand: Department of Fisheries, Ministry of Agriculture and Cooperatives, 2013.

[9] National Metal and Materials Technology Centre (MTEC) and University of Paya, Progress Report of National Life Cycle Inventories of Food and Agriculture, 2013.

[10] IPCC, "Energy," in 2006 IPCC Guidelines for National Greenhouse Gas Inventories, H. S. Eggleston, L. Buendia, K. Miwa, T. Ngara, K. Tanabe, Ed. Japan: IGES, 2006, vol. 2, ch. 2, pp. 2-22. 2006.

[11] K. Kubica, B. Paradiz, P. Dilara, Z. Klimont, S. Kakareka, B. Debsk, M. Woodfield, and R. Stewart, "Small Combustion," in EMEP/EEA air pollutant emission inventory guidebook 2009, European Environmental Agency, Copenhagen, pp. 26-28, 2009.

[12] I. Vazquez-Rowe, H. Alumudena, M. T. Moreira, and F. Gumersindo. (December 2012). Best practices in life cycle assessment implementation in fisheries. Improving and broadening environmental assessment for seafood production systems. Trends Food Sci Tech. [Online]. 28(2). pp. 116-131. Available: http://www.sciencedirect.com/science/article/pii/S092422441200146 $\mathrm{X}$.

[13] B. Samuel-Fitwi, F. Nagel, S. Meyer, J. P. Schroeder, and C. Schulza. (May 2013). Comparative life cycle assessment (LCA) of raising rainbow trout (Oncorhynchus mykiss) in different production systems. Aquacult Eng. [Online]. vol. 54. pp. 85-92. Available: http://www.sciencedirect.com/science/article/pii/S0144860912000994

[14] N. W. Ayer and P. H. Tyedmers. (February 2009). Assessing alternative aquaculture technologies: life cycle assessment of salmonid culture systems in Canada. J Clean Prod. [Online]. vol. 17. no. 3. pp. 362-373. Available: http://www.sciencedirect.com/science/article/pii/ S0959652608001820

[15] S. Y. Shiau, J. L. Chuang, and C. L. Sun. (September 1987). Inclusion of soybean meal in tilapia (Oreochromis niloticus $\times \mathrm{O}$. aureus) diets at two protein levels. Aquaculture. [Online]. vol. 65. no. 3-4. pp. 251-261. Available: http://www.sciencedirect.com/science/article/pii/0044848 687902389.

[16] National Metal and Materials Technology Centre (MTEC) and Thailand Environment Institute, Report of National Life Cycle Inventories of Feeds, 2009.

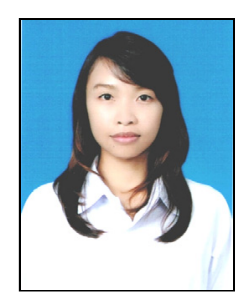

Patcharaporn Pongpat is a Engineer with Life Cycle Assessment Laboratory, National Metal and Materials Technology Centre (MTEC), National Science and Technology Development Agency (NSTDA). She is completing her master's degree in Energy engineering at Chiang Mai University, Thailand.

She started to work as engineer at life cycle assessment (LCA) laboratory at MTEC since 2012, her work responsibilities focus on on national life cycle inventory (LCI) establishment and research consultant for private companies relating to environmental assessment. 


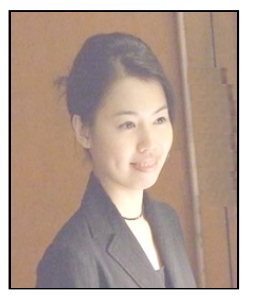

Rungnapa Tongpool was born in Thailand. She graduated at Kasetsart University, Thailand and got her Master and $\mathrm{PhD}$ degree in Materials Science in 2000 from University of Manchester Institute of Science and Technology (UMIST), Manchester, UK.

She started her career as a researcher at National Metal and Materials Technology Center (MTEC), Thailand in 2000. In the first seven years, her work had focused on materials research such as gas sensing materials, photocatalyst, dye sensitized solar cell, UV and IR preventive film. Then she joined life cycle assessment (LCA) laboratory at MTEC which carries on national life cycle inventory (LCI) establishment. The national LCI has been applied in carbon footprint calculation and environmental assessment of commercial products. She is one of the committee, setting up national Carbon footprint scheme. Now she holds the position as LCA lab head and principal researcher. Her main task is to initiate national LCl covering agriculture and basic materials as well as to give consultancy to private companies relating to environmental assessment.

Dr. Tongpool achieved gold medal from Agriculture-HorticultureGardening Section, $34^{\text {th }}$ International Exhibition of Inventions, New Techniques and Products, Geneva, in 2006, on her invention "zip-lock paper bag". She wrote the book "Establishment of Thai National Life Cycle Inventory Database, Pathumthani, NSTDA, 2012 (ISBN: 978-616-12-01760 ) according to her experience on LCI and LCA. Her recent article is "Improvement of the environmental performance of broiler feeds: a study via life cycle assessment", published in Journal of Cleaner Production, 2012. 